\title{
Histone-Lysine N-Methyltransferase KMT5B
}

National Cancer Institute

\section{Source}

National Cancer Institute. Histone-Lysine N-Methyltransferase KMT5B. NCI Thesaurus. Code C73699.

Histone-lysine N-methyltransferase KMT5B ( $855 \mathrm{aa}, \sim 99 \mathrm{kDa}$ ) is encoded by the human KMT5B gene. This protein may play a role in repression of transcription by RNA polymerase II, and in establishment of pericentric heterochromatin domains. 